\title{
PENGUKURAN KINERJA DENGAN PRINSIP VALUE FOR MONEY PEMERINTAH KOTA BATU
}

\author{
Sri Andriani \\ Fakultas Ekonomi,Universitas Islam Negeri Maulana Malik Ibrahim Malang \\ Jl. Gajayana 50 Malang Telp. 0341-551354 Faks. 0341-572533 \\ email: sriandrianiuin@gmail.com/No Telepon 081333689915
}

\begin{abstract}
This research is to measure the service has been conducted by the government of Batu City using two data analysis, are monetary performance ratio and value for money. The performance of Batu government measured using value for money classified into three those are: economy, efficienty, and effectiveness. The performance of Batu government in economy based on how to realize the fund, the performance of Batu government in efficienty based on the reality of credit (the outcome) of fund is higher than the debet (income) and based on the effectiveness because realization of revenue greater than budget revenue. The performance of Batu government measured using monetary performance ratio classified into five: effetiveness, efficiency, independence, activity and Debt Service Coverage Ratio (DSCR). The performance of Batu government is less effective in realizing the income, however the goverment is efficient enough, thought it has been inreasing in 2009. Batu government has been independence, because it could decrease and keep in depending toward external side (exspecially toward central and province government), Batu government measured using activity ratio, most of the fund is given to local apparatus needs, so the expense of public service toward local expense fund is relatively small, and based on DSCR Batu government is good.
\end{abstract}

Keyword: public, monetary performance, value for money

\section{PENDAHULUAN}

Pemerintah di tingkat daerah memiliki peran yang sangat menyentuh kehidupan masyarakat dalam hal kualitas jasa yang menjadi pusat layanan bagi masyarakat. Perubahan lingkungan yang terus berlangsung sangat cepat mengharuskan setiap organisasi untuk dapat dengan cepat dan tepat beradaptasi dengan perubahan dengan secara cerdas menerapkan berbagai metode pengelolaan organisasi sesuai dengan pengelolaan sumber-sumber ekonomis erat kaitannya dengan pengelolaan keuangan, yang merupakan aspek penting dalam penyelenggaraan pembangunan dan pemerintahan. Kepercayaan dan kepuasan masyarakat menjadi tujuan dalam penyelenggaran pemeritahan, artinya masyarakat harus bisa terlanyani dengan baik. 
Peraturan atau ketentuan tentang penyelenggaraan pelayanan publik wajib disesuaikan dengan Undang-Undang terbaru yaitu Nomor 25 Tahun 2009 tentang Pelayanan Publik. Undang-Undang Pelayanan Publik ini diterbitkan dengan harapan mewujudkan penyelenggaraan pelayanan publik yang prima, memenuhi asas-asas umum pemerintahan yang baik, dan terjaminnya kepastian hak dan kewajiban serta kepastian hukum dalam penyelenggaraan pelayanan publik. Undang-Undang Pelayanan publik ini juga memberikan sanksi bagi pelaksana dan penyelenggara pelayanan publik yang tidak memenuhi ketentuan dalam Undang-Undang ini. Ketentuan tentang sanksi ini menunjukkan tingginya tuntutan untuk memenuhi harapan masyarakat dalam mendapatkan pelayanan yang baik dari para penyelenggara pelayanan publik, Syahputri (2011). Sisi lain hasil survey yang dilakukan Komisi Pemberantasan Korupsi menunjukkan bahwa pelayanan yang dilakukan 20 Satuan Kerja Perangkat Daerah (SKPD) di 22 pemerintah kota di Indonesia masih sangat buruk, Kompas (2011)

Pelayanan public yang diberikan kemasyarakat menggunakan dana yang berasal dari APBD, sehingga dilakukan pertanggungjawaban pada masyarakat, maka konsep pengukuran kinerja juga perlu dilakukan. Prinsip value for money dalam rangkapengukuran kinerja dipengaruhi oleh kemampuan pemerintah daerah dalam melaksanakan mekanisme manajemen pemerintahannya yang bertumpu pada tiga dimensi penting, yaitu: perencanaan, pelaksanaan dan pengendalian.

Pemerintah Daerah Kota Batu yang sekarang sudah menjadi kota wisata pasti akan selalu di tuntut untuk memberikan pelayanan jasa yang lebih baik lagi, sebagai contoh dalam rangka menunjang tahun kunjungan wisata Jatim 2011 (visit of east java 2011), pelayanan kepada wisatawan terus ditingkatkan, diantaranya pelayanan di bidang transportasi, pegembangan daerah wisata

Dari uraian pendahulan diatas maka permasalahannya adalah Bagaimanakah kinerja dengan prinsip value for money Pemerintah Daerah Kota Batu?

\section{Landasan Penelitian Terdahulu}

Beberapa penelitian yang telah dilakukan tentang Kinerja Pemkot Malang dengan penerapan otonomi daerah cukup baik. Hal ini ditunjukkan dengan tiga rasio yaitu rasio efektivitas rata-rata sebelum otonomi daerah sebesar 100,24\% dan sesudah otonomi daerah menjadi sebesar $112,38 \%$, rasio efisien rata-rata 
sebelum otonomi daerah sebesar $4,09 \%$ dan sesudah otonomi daerah menjadi sebesar $3.03 \%$, debs service coverage ratio (DSCR) yang setiap tahunnya mengalami kenaikan, dan rasio pertumbuhan yang juga mengalami kenaikan setiap tahunnya. Tetapi rasio kemandirian mengalami penurunan sebelum otonomi daerah sebesar 13,10\%. (Suyono 2004:80). Kinerja pemerintah kota Blitar dalam menghemat biaya sudah tercapai hal ini ditunjukkan dengan semakin berkurangnya pos-pos yang tidak ekonomis dari tahun ke tahun, selain itu hasil rasio ekonomi berada dibawah $100 \%$. Hasil perhitungan rasio efisiensi menunjukkan bahwa kinerja Pemerintah kot Blitar cukup efisien, hal ini bisa dilihat pada tahun 2005 yang mengalami penurunan dari tahu 2004 dan ini berarti kinerja Pemkot dalam memungut pendapatan asli daerah cukup efisien karena pada tahun 2005 tingkat pendapatan asli daerah dalam hal ini pada pos lain-lain pendapatan yang sah menurun dari tahun 2004 sebesar Rp. 12.578.790.304,00 menjadi Rp. 5.763.870.602,00 pada tahun 2005. Sedangkan hasil perhitungan rasio efektifitas menunjukan bahwa kinerja pemerintah kota Blitar dalam merealisasikan PAD sudah efektif, karena rasio efektifitasnya menunjukkan hasil lebih dari 100\%. (Yuanda (2007:75).

Perbedaaan antara peneliti terdahulu dengan peneliti sekarang yaitu perbedaannya terletak pada objek yang diteliti dan pada alat analisis yang digunakan. Peneliti terdahulu hanya menggunakan value for money sedangkan penelitian yang sekarang menggunakan value for money dan analisis rasio keuangan.

\section{METODE PENELITIAN}

Lokasi penelitian dilakukan pada Pemerintah Daerah Kota Batu di Jl. Panglima Sudirman No. 98. Data yang digunakan adalah data kuantitatif yaitu data penelitian berupa angka-angka dan analisis menggunakan statistik dan data kualitatif yaitu data hasil penelitian lebih berkenaan dengan intreprestasi terhadap data yang ditemukan dilapangan (Sugiyono, 2011:7). Data kuantitatif yang digunakan adalah ringkasan laporan realisasi APBD Pemerintah Daerah Kota Batu periode 2005-2009. Data diambil dari dokumen perhitungan anggaran pendapatan dan belanja daerah (APBD) Pemerintah Daerah Kota Batu yang diperoleh dari bagian keuangan dan website Pemerintah Daerah Kota Batu dari tahun 2005-2009. 


\section{PEMBAHASAN}

\section{Data Keuangan}

Peneliti dalam penelitiannya data-data yang diambil adalah APBD/RAPBD Pemerintah Daerah Kota Batu dengan tahun periode dari 2005 sampai dengan 2009. Data Anggaran Pendapatan Belanja Daerah (APBD) dan Realisasi Anggaran Pendapatan Belanja Daerah (RAPBD) Pemerintah Daerah Kota Batu yang sudah diolah oleh peneliti sebagai berikut:

Tabel 4.1

Anggaran Pendapatan Belanja Daerah (APBD) dan RAPBD Pemerintah Daerah Kota Batu Tahun 2005

\begin{tabular}{|c|c|c|c|}
\hline No & Uraian & $\begin{array}{l}\text { Anggaran Setelah } \\
\text { Perubahan (Target) }\end{array}$ & $\begin{array}{c}\text { Realisasi } \\
\text { Penerimaan/Belanj } \\
\text { a }\end{array}$ \\
\hline \multirow[t]{13}{*}{1} & Pendapatan Asli Daerah & $8.192 .582 .863,00$ & $8.415 .307 .033,78$ \\
\hline & Pajak Daerah & 4.929.339.000,00 & $5.289 .255 .314,00$ \\
\hline & Retribusi Daerah & 2.040.409.300,00 & $1.969 .770 .218,00$ \\
\hline & $\begin{array}{l}\text { Hsl. Persh. Milik Daerah \& } \\
\text { Pengelolaan Kekayaan. Daerah }\end{array}$ & $175.000 .000,00$ & $520.582 .749,54$ \\
\hline & $\begin{array}{l}\text { Lain-lain Pendapatan Asli Daerah } \\
\text { Yang Sah }\end{array}$ & $1.047 .834 .563,00$ & $635.698 .752,24$ \\
\hline & Dana Perimbangan & 137.537.348.923,00 & 143.473.041.136,00 \\
\hline & Bagi Hasil Pajak dan Bukan Pajak & $13.535 .843 .764,00$ & $16.387 .367 .844,00$ \\
\hline & Dana Alokasi Umum & $104.489 .000 .000,00$ & $104.489 .000 .000,00$ \\
\hline & Dana Alokasi Khusus & $10.650 .000 .000,00$ & $10.650 .000 .000,00$ \\
\hline & $\begin{array}{l}\text { Bagi Hsl.Pajak \& Bantuan Keu. Dari } \\
\text { Propinsi }\end{array}$ & $8.862 .505 .177,00$ & $11.946 .673 .292,00$ \\
\hline & Lain-lain Pendapatan yang Sah & $17.354 .230 .000,00$ & $17.354 .000 .000,00$ \\
\hline & $\begin{array}{l}\text { Bant.Dn.Kontijensi/Penyeimbang dari } \\
\text { Pemerintah }\end{array}$ & $17.354 .230 .000,00$ & $17.354 .000 .000,00$ \\
\hline & Jumlah Pendapatan & 163.084 & $169.242 .348 .169,78$ \\
\hline \multirow[t]{16}{*}{2} & Aparatur & $78.090 .187 .673,00$ & 71.824.348.169,78 \\
\hline & Belanja Administrasi Umum & $54.897 .671 .097,00$ & $50.237 .443 .180,60$ \\
\hline & i/Personalia & $42.590 .848 .390,00$ & $39.065 .298 .593,90$ \\
\hline & dan Jasa & $16.232 .150 .867,00$ & $14.624 .433 .979,40$ \\
\hline & Belanja Perjalanan Dinas & $5.014 .368 .400,00$ & 4.496.022.000,00 \\
\hline & Belanja Pemeliharaan & 2.699.563.040,00 & 2.618.572.775,90 \\
\hline & $\begin{array}{l}\text { Belanja Operasional dan } \\
\text { Pemeliharaan }\end{array}$ & $11.610 .378 .600,00$ & $10.439 .370 .700,00$ \\
\hline & Belanja Pegawai/Personalia & - & - \\
\hline & dan Jasa & - & - \\
\hline & Belan & - & \\
\hline & Belanja Pemeliharaan & - & \\
\hline & Belanja Modal & $10.326 .381 .495,00$ & $9.840 .115 .977,00$ \\
\hline & Pelayanan Publik & 93.332.295.473,00 & $89.563 .727 .025,60$ \\
\hline & Belanja Administrasi Umum & 28.586.925.023,00 & 27.525.689.34 \\
\hline & Belanja Pegawai / Personalia & 24.647.006.673,00 & 23.633.835.316,70 \\
\hline & Belanja Barang dan Jasa & $12.070 .979 .920,00$ & $11.922 .436 .608,00$ \\
\hline
\end{tabular}




\begin{tabular}{|c|c|c|c|}
\hline & elanja Perjalanan Dinas & $918.335 .000,00$ & $848.401 .000,00$ \\
\hline & Belanja Pemeliharaan & 7.044.719.500,00 & $6.758 .530 .100,00$ \\
\hline & Belanja Operasinal dan Pemeliharaan & 16.139.916.070,00 & $15.685 .172 .880,00$ \\
\hline & Belanja Pegawai / Personalia & - & \\
\hline & Irang dan Jasa & - & \\
\hline & erjalana & - & \\
\hline & emeliharaan & - & - \\
\hline & Modal & 24.794.227.350,00 & 23.480 \\
\hline & $\begin{array}{l}\text { Belanja Bagi Hasil \& Bantuan } \\
\text { Keuangan }\end{array}$ & $6.863 .800 .000,00$ & $6.691 .450 .000,00$ \\
\hline & Belanja Tak Terduga & $2.500 .000 .000,00$ & 1.792 .42 \\
\hline & Jumlah Belanja & 171.422.483.146,00 & $\begin{array}{l}161.388 .302 .694,9 \\
0\end{array}$ \\
\hline & Surplus / (Defisit) & $(8.338 .321 .360,00)$ & $7.854 .045 .474,88$ \\
\hline 3 & Penerimaan Daerah & 24.350.716.979,00 & 24.350.664.764,39 \\
\hline & Sisa Lebih Perhit. Anggaran Tahun Lalu & 6.655 .664 & $6.655 .664 .764,39$ \\
\hline & Dana Cadangan & - & \\
\hline & Penerimaan Pinjaman dan Obligasi & $17.695 .052 .214,61$ & $17.695 .000 .000,00$ \\
\hline & $\begin{array}{l}\text { Hasil Penjual. Aset Daerah yang } \\
\text { Dipisahkan }\end{array}$ & - & \\
\hline & $\begin{array}{l}\text { Penerimaan Piutang Lain-lain Tahun } \\
\text { Lalu }\end{array}$ & - & \\
\hline & Pengeluaran Daerah & 16.150 .000 & 32.315.202.040,97 \\
\hline & dangan & 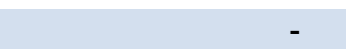 & \\
\hline & Penyerta & $400.000 .000,00$ & $552.000 .000,00$ \\
\hline & $\begin{array}{l}\text { Pembayaran Utang Pokok Yang Jatuh } \\
\text { Tempo }\end{array}$ & 15.750 .000 & $15.750 .000 .000,00$ \\
\hline & $\begin{array}{l}\text { Sisa Lebih Perhit. Anggaran Thn } \\
\text { Berjalan }\end{array}$ & - & 16.013.202.040,97 \\
\hline & Jumlah Pembiayaan & 200.71 & 5,36 \\
\hline
\end{tabular}

Sumber: Bag. Keu. Pemerintah Daerah Kota Batu, 2005, Diolah

\section{Analisa Data}

Mengukur kinerja Pemerintah Daerah Kota Batu penulis menggunakan RAPBD dan APBD Pemerintah Daerah Kota Batu dengan tahun anggaran 2005 sampai dengan tahun anggaran 2009, sedangkan untuk analisis datanya penulis menggunakan dua metode analisis data yaitu: 


\section{Rasio Kinerja Value For Money}

\section{Rasio Ekonomis}

Ekonomis (kehematan) sebagai tingkat biaya yang dikeluarkan untuk melaksanakan suatu kegiatan atau memperoleh sesuatu. Tingkat ekonomis sebuah anggaran bisa dilihat dari berapa presentase tingkat pencapaian. Tingkat ekonomi dalam mengelola keuangan dengan melihat perbandingan antara anggaran belanja dengan realisasinya dengan presentase tingkat pencapaiannya.

Rasio Ekonomis $\quad=\quad \frac{\text { Realisasi Pengeluaran }}{\text { Anggaran Pengeluaran }} \times 100 \%$

Ketentuan:

(a) Jika $<100 \%$ berarti Ekonomis

(b) Jika $>100 \%$ berarti Tidak Ekonomis

(c) Jika $=100 \%$ berarti Ekonomis Berimbang

Ilustrasi perhitungan rasio ekonomis untuk Pemerintah Daerah Kota Batu tahun anggaran 2005 yang diambil dari APBD adalah:

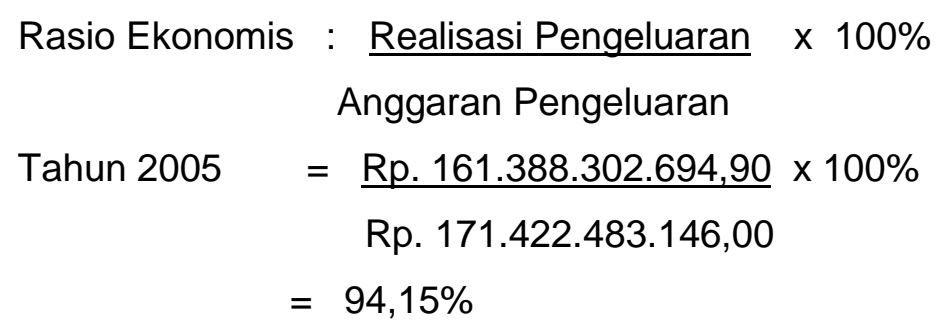

Berdasarkan ilustrasi di atas penulis dapat memberikan penjelasan untuk penerapan pengukuran kinerja value for money pada Pemerintah Daerah Kota Batu dengan menggunakan Rasio Ekonomis menunjukkan hasil perhitungan 94,15\%. Hal ini menunjukkan kinerja Pemerintah Daerah Kota Batu tahun 2005 ekonomis karena hasil perhitungannya kurang dari 100\%.

Perhitungan rasio ekonomis tahun anggaran 2006 sampai dengan tahun anggaran 2009 dapat dilihat di lampiran 5. Tabel perkembangan rasio ekonomis Pemerintah Daerah Kota Batu tahun anggaran 2005 sampai dengan tahun anggaran 2009.

Tabel 4.2: Perkembangan Rasio Ekonomis Pemerintah Daerah Kota Batu Tahun 2005-2009

\begin{tabular}{cc}
\hline Tahun & Rasio ekonomi \\
\hline 2005 & $94,15 \%$ \\
\hline
\end{tabular}




\begin{tabular}{ll}
\hline 2006 & $93,36 \%$ \\
2007 & $84,35 \%$ \\
2008 & $80,79 \%$ \\
2009 & $89,08 \%$ \\
\hline
\end{tabular}

Sumber: Pemda Kota Batu Tahun 2005-2009, Diolah

Berdasarkan tabel 4.2 dapat di simpulkan pada tahun anggaran 2005 ke tahun anggaran 2006 mengalami penurunan sebanyak $0,79 \%$ yaitu dari $94,15 \%$ menjadi 93,36\%, pada tahun anggaran 2006 ke tahun anggaran 2007 mengalami penurunan sebanyak $9,01 \%$ yaitu dari $93,36 \%$ menjadi $84,35 \%$, pada tahun anggaran 2007 ke tahun anggaran 2008 mengalami penurunan sebesar $3,56 \%$ yaitu dari $84,35 \%$ menjadi $80,79 \%$, dan pada tahun anggaran 2008 ke tahun anggaran 2009 mengalami kenaikan sebesar 8,29\% yaitu dari 80,79\% menjadi $89,08 \%$.

Grafik pengukuran kinerja value for money untuk rasio ekonomis dari tahun anggaran 2005 sampai dengan tahun anggaran 2006 sebagai berikut:

Grafik 4.1

Perkembangan Rasio Ekonomis Pemerintah Daerah Kota Batu Tahun anggaran 2005-2009

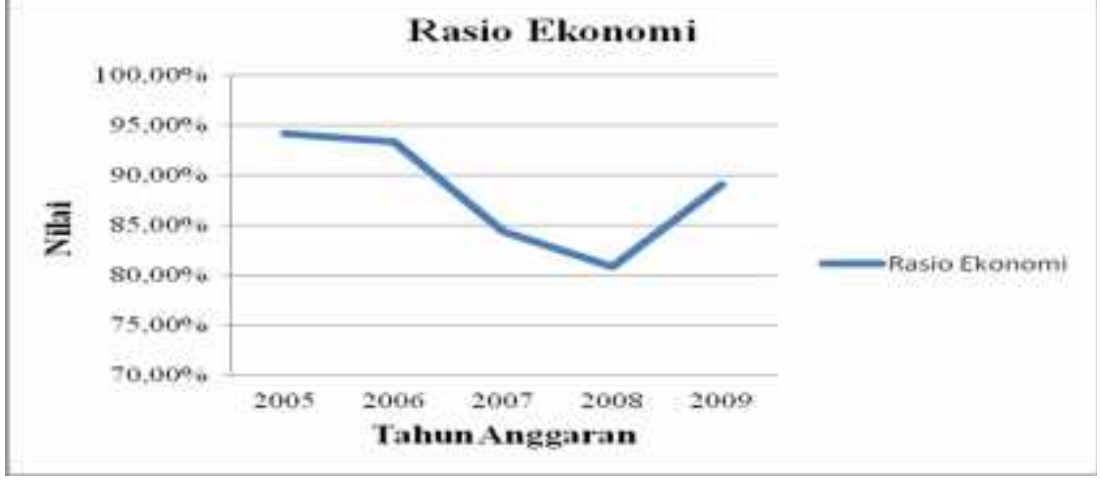

Berdasarkan grafik 4.1 dapat dilihat naik turun pada tahun anggaran 2005 ke 2006 mengalami penurunan sedangkan pada tahun anggaran 2006 ke 2008 mengalami penurunan. Di tahun 2008 ke 2009 mengalami kenaikan.

\section{Rasio Efisiensi}

Efisiensi (daya guna) berhubungan dengan metode operasi (method operation). Proses kegiatan operasional dapat dikatakan efisien apabila suatu produk atau hasil karya tertentu mempergunakan sumber daya dan dana yang serendah rendahnya. Efisiensi merupakan perbandingan antara output dan input. Tingkat efisiensi dalam mengelola keuangan dengan melihat 
perbandingan antara realisasi anggaran pendapatan dengan realisasi anggaran belanja.

Rasio Efisiensi = Realisasi Biaya untuk Memperoleh Pendapatan $\times 100 \%$ Realisasi Pendapatan

Ketentuan :

(a) Jika $<100 \%$ berarti efisien

(b) Jika $>100 \%$ berarti tidak efisien

(c) Jika $=100 \%$ berarti efisien berimbang

Ilustrasi perhitungan rasio efisiensi untuk Pemerintah Daerah Kota Batu tahun anggaran 2005 yang diambil dari APBD adalah:

Rasio Efisiensi $=$ Realisasi Biaya untuk Memperoleh Pendapatan $\times 100 \%$ Realisasi Pendapatan

Tahun $2005=$ Rp. $161.388 .302 .694,90 \times 100 \%$ Rp. $169.242 .348 .169,78$

$=95,36 \%$

Berdasarkan ilustrasi di atas penulis dapat memberikan penjelasan untuk penerapan pengukuran kinerja value for money pada Pemerintah Daerah Kota Batu dengan menggunakan rasio efisiensi menunjukkan hasil perhitungan 95,36\%. Hal ini menunjukkan kinerja Pemerintah Daerah Kota Batu tahun 2005 efisien karena hasil perhitungannya kurang dari 100\%.

Perhitungan rasio efisiensi tahun anggaran 2006 sampai dengan tahun anggaran 2009 dapat dilihat di lampiran 6. Tabel perkembangan rasio efisiensi Pemerintah Daerah Kota Batu tahun anggaran 2005 sampai dengan tahun anggaran 2009.

Tabel 4.3

Perkembangan Rasio Efisiensi Pemerintah Daerah Kota Batu Tahun 20052009

\begin{tabular}{cc}
\hline Tahun & Rasio Efisiensi \\
\hline 2005 & $95,36 \%$ \\
2006 & $89,09 \%$ \\
2007 & $89,71 \%$ \\
2008 & $91,89 \%$ \\
2009 & $107,31 \%$ \\
\hline Sumber: Bag. Keu. Pemerintah Daerah Kota Batu, 2005-2009, Diolah
\end{tabular}


Berdasarkan tabel 4.3 dapat di simpulkan bahwa pada Tahun anggaran 2005 ke Tahun anggaran 2006 mengalami penurunan sebanyak 6,27\% yaitu dari 95,36\% menjadi 89,09\%, pada Tahun Anggran 2006 ke Tahun anggaran 2007 mengalami kenaikan sebanyak 0,62\% yaitu dari 89,09\% menjadi 89,71\%, pada Tahun Anggatan 2007 ke Tahun anggaran 2008 mengalami kenaikan sebesar $2,18 \%$ yaitu dari $89,71 \%$ menjadi $91,89 \%$, dan pada tahun anggaran 2008 ke tahun anggaran 2009 mengalami kenaikan sebesar $15,42 \%$ yaitu dari $91,89 \%$ menjadi $107,31 \%$.

Grafik pengukuran kinerja value for money untuk rasio efisiensi sebagai berikut:

Grafik 4.2

Perkembangan Rasio Efisiensi Pemerintah Daerah Kota Batu Tahun anggaran 2005-2009

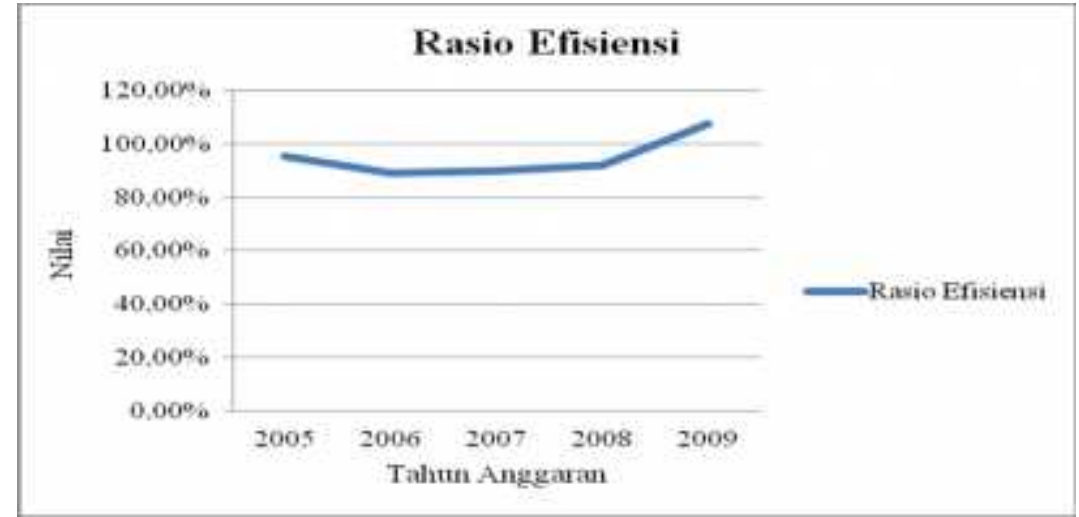

Sumber: Pemda Kota Batu Tahun 2005-2009, Diolah

Berdasarkan grafik 4.2 dapat dilihat naik turun pada tahun anggaran 2005 ke 2006 mengalami penurunan sedangkan pada tahun anggaran 2006 ke 2007 mengalami kenaikan. Di tahun anggaran 2007 ke 2008 mengalami kenaikan sedangkan pada tahun 2008 ke 2009 kembali mengalami kenaikan yang drastis.

\section{Rasio Efektifitas}

Efektivitas (hasil guna) adalah ukuran keberhasilan suatu organisasi dalam usaha mencapai tujuan organisasi yang telah ditetapkan. Efektifitas merupakan perbandingan outcome dan output. Outcome merupakan dampak suatu program atau kegiatan terhadap masyarakat sedangkan output merupakan hasil yang dicapai dari suatu program aktivitas dan kebijakan. Tingkat efektifitas dalam pengelolaan keuangan dapat dilihat perbandingan 
anggaran pendapatan dengan realisasinya dan presentase tingkat pencapainnya.

Rasio Efektifitas : Realisasi Pendapatan x 100\% Anggaran Pendapatan

Ketentuan :

(a) Jika $>100 \%$ berarti efektif

(b) Jika $<100 \%$ berarti tidak efektif

(c) Jika $=100 \%$ berarti efektifitas berimbang

Ilustrasi perhitungan rasio efektifitas untuk Pemerintah Daerah Kota Batu tahun anggaran 2005 yang diambil dari APBD adalah:

Rasio Efektifitas : Realisasi Pendapatan x 100\%

Anggaran Pendapatan

Tahun $2005=$ Rp. 169.242.348.169,78 $\times 100 \%$

Rp. 163.084.161.786,00

$=103,78 \%$

Berdasarkan ilustrasi di atas penulis dapat memberikan penjelasan untuk penerapan pengukuran kinerja value for money pada Pemerintah Daerah Kota Batu dengan menggunakan rasio efektifitas menunjukkan hasil perhitungan 103,78\%. Hal ini menunjukkan kinerja Pemerintah Daerah Kota Batu tahun 2005 efektif karena hasil perhitungannya kurang dari 100\%.

Perhitungan rasio efektifitas tahun anggaran 2006 sampai dengan tahun anggaran 2009 dapat dilihat di lampiran 7. Tabel perkembangan rasio efektifitas Pemerintah Daerah Kota Batu tahun anggaran 2005 sampai dengan tahun anggaran 2009.

Tabel 4.4

Perkembangan Rasio Efektifitas Pemda Kota Batu Tahun 2005-2009

\begin{tabular}{cc}
\hline Tahun & Rasio Efektifitas \\
\hline 2005 & $103,78 \%$ \\
2006 & $102,78 \%$ \\
2007 & $100,00 \%$ \\
2008 & $96,56 \%$ \\
2009 & $97,88 \%$ \\
\hline umber: Bag. Keu. Pemerintah Daerah Kota Batu, 2005-2009, Diolah
\end{tabular}

Berdasarkan tabel 4.4 dapat disimpulkan tahun anggaran 2005 ke tahun anggaran 2006 mengalami penurunan sebanyak 1\% yaitu dari 103,78\% menjadi 102,78\%, pada tahun anggran 2006 ke tahun anggaran 2007 mengalami penurunan sebanyak $2,78 \%$ yaitu dari $102,78 \%$ menjadi $100,00 \%$, 
pada tahun angkatan 2007 ke tahun anggaran 2008 mengalami penurunan sebesar $3,44 \%$ yaitu dari $100,00 \%$ menjadi $96,56 \%$, dan pada tahun anggaran 2008 ke tahun anggaran 2009 mengalami kenaikan sebesar 1,32\% yaitu dari $96,56 \%$ menjadi $97,88 \%$.

Grafik pengukuran kinerja value for money untuk rasio efektifitas sebagai berikut:

\section{Grafik 4.3 \\ Perkembangan Rasio Efektifitas Pemerintah Daerah Kota Batu Tahun anggaran 2005-2009}

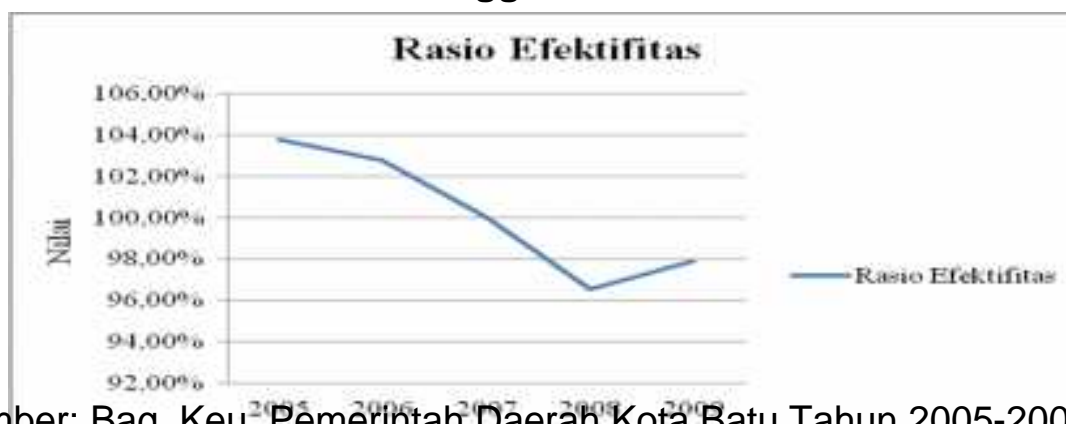

Sumber: Bag. Keu:Pềmênintahtả Dảerảh Kotà Batu Tahun 2005-2009, Diolah

Berdasarkan grafik 4.3 dapat dilihat naik turun pada tahun anggaran 2005 ke 2006 mengalami penurunan sedangkan pada tahun anggaran 2006 sampai ke tahun anggaran 2008 mengalami penurunan pada tahun 2008 ke 2009 kembali mengalami kenaikan.

\section{Analisis Rasio Keuangan}

\section{Rasio Efektifitas}

Rasio efektifitas menggambarkan kemampuan Pemerintah daerah dalam meralisasikan PAD yang direncanakan dibandingkan dengan target yang ditetapkan berdasarkan potensi rill daerah. Kemampuan daerah dalam menjalankan tugas dikategorikan efektif apabila rasio yang dicapai minimal sebesar satu atau 100\%. Semakin tinggi rasio efektifitas, maka kemampuan daerah pun semakin baik.

$$
\text { Rasio Efektifitas : } \frac{\text { Realisasi Penerimaan PAD }}{\text { Target Penerimaan PAD }}
$$

Ilustrasi perhitungan rasio efektifitas untuk Pemerintah Daerah Kota Batu tahun anggaran 2005 yang diambil dari APBD adalah: 


\section{Rasio Efektifitas : Realisasi Penerimaan PAD \\ Target Penerimaan PAD}

$$
\text { Tahun } \begin{aligned}
2005 & =\frac{169 \cdot 242 \cdot 348 \cdot 169,78}{163 \cdot 084 \cdot 161 \cdot 786,00} \\
& =103,78 \%
\end{aligned}
$$

Berdasarkan ilustrasi di atas penulis dapat memberikan penjelasan untuk penerapan pengukuran kinerja rasio kinerja keuangan pada Pemerintah Daerah Kota Batu dengan menggunakan Rasio Efektifitas menunjukkan hasil perhitungan 103,78\%. Hal ini menunjukkan kinerja Pemerintah Daerah Kota Batu tahun 2005 efektif berarti kemampuan Pemerintah Daerah Kota Batu dalam menjalankan tugas semakin baik.

Perhitungan rasio efektifitas tahun anggaran 2006 sampai dengan tahun anggaran 2009 dapat dilihat di lampiran 8. Tabel perkembangan rasio efektifitas Pemerintah Daerah Kota Batu tahun anggaran 2005 sampai dengan tahun anggaran 2009.

Tabel 4.5

Perkembangan Rasio Efektifitas Pemerintah Daerah Kota Batu Tahun 2005-2009

\begin{tabular}{cc}
\hline Tahun & Rasio Efektifitas \\
\hline 2005 & $103,78 \%$ \\
2006 & $102,78 \%$ \\
2007 & $100,24 \%$ \\
2008 & $96,56 \%$ \\
2009 & $97,88 \%$ \\
\hline
\end{tabular}

Sumber: Bag. Keu. Pemerintah Daerah Kota Batu, 2005-2009, Diolah

Berdasarkan tabel 4.5 di atas dapat disimpulkan tahun anggaran 2005 ke tahun anggaran 2006 mengalami penurunan sebesar 1\% dari 103,78\% menjadi 102,78\%, di tahun anggaran 2006 ke tahun anggaran 2007 mengalami penurunan sebesar $2,54 \%$ yaitu dari $102,78 \%$ menjadi $100,24 \%$, di tahun anggaran 2007 ke tahun anggaran 2008 juga mengalami penurunan sebesar $3,68 \%$ dari $100,24 \%$ menjadi $96,56 \%$, yang terakhir tahun anggaran 2008 ke tahun 2009 mengalami kenaikan sebesar 1,32\% dari 96,56\% menjadi $97,88 \%$. 


\section{Rasio Efisiensi}

Rasio Efisiensi menggambarkan perbandingan antara besarnya biaya yang dikeluarkan untuk memperoleh pendapatan dibandingkan dengan realisasi pendapatan yang diterima. Kinerja Pemda dalam melakukan pemungutan pendapatan dikatagorikan efisien apabila rasio di capai kurang dari satu atau di bawah $100 \%$. Semakin kecil rasio efisiensi berarti kinerja pemerintah daerah semakin baik.

\section{Rasio Efisiensi $=\underline{\text { Biaya yang dikeluarkan untuk PAD }}$}

Realisasi Penerimaan PAD

Ilustrasi perhitungan rasio efisiensi untuk Pemerintah Daerah Kota Batu tahun anggaran 2005 yang diambil dari APBD adalah:

Rasio Efisiensi : Biaya yang dikeluarkan untuk PAD

Realisasi Penerimaan PAD

$$
\text { Tahun } \begin{aligned}
2005 & =\frac{161 \cdot 388 \cdot 302 \cdot 694,00}{169 \cdot 242 \cdot 348 \cdot 169,78} \\
& =95,36 \%
\end{aligned}
$$

Berdasarkan ilustrasi di atas penulis dapat memberikan penjelasan untuk penerapan pengukuran kinerja rasio kinerja keuangan pada Pemerintah Daerah Kota Batu dengan menggunakan Rasio Efisiensi menunjukkan hasil perhitungan 95,36\%. Hal ini menunjukkan kinerja Pemerintah Daerah Kota Batu dalam memungut pendapatan pada tahun 2005 semakin baik.

Perhitungan rasio efisiensi tahun anggaran 2006 sampai dengan tahun anggaran 2009 dapat dilihat di lampiran 9. Tabel perkembangan rasio efisiensi Pemerintah Daerah Kota Batu tahun anggaran 2005 sampai dengan tahun anggaran 2009.

Tabel 4.6

Perkembangan Rasio Efisiensi Pemerintah Daerah Kota Batu Tahun 2005-2009

\begin{tabular}{cc}
\hline Tahun & Rasio Efisiensi \\
\hline 2005 & $95,36 \%$ \\
2006 & $89,09 \%$ \\
2007 & $89,71 \%$ \\
2008 & $91,88 \%$ \\
\hline
\end{tabular}




$\frac{1009}{107,31 \%}$

Berdasarkan tabel di atas dapat disimpulkan bahwa tahun anggaran 2005 ke tahun anggaran 2006 mengalami penurunan sebesar 6,27\% dari 95,36\% menjadi 89,09\%, di tahun anggaran 2006 ke tahun anggaran 2007 mengalami kenaikan sebesar $0,62 \%$ yaitu dari $89,09 \%$ menjadi $89,71 \%$, di tahun anggaran 2007 ke tahun anggaran 2008 juga mengalami kenaikan sebesar $2,17 \%$ dari $89,71 \%$ menjadi $91,88 \%$, yang terakhir tahun anggaran 2008 ke tahun 2009 mengalami kenaikan sangat drastis sebesar 15,43\% dari $91,88 \%$ menjadi $107,31 \%$.

\section{Rasio Kemandirian}

Rasio ini ditujukan untuk mengukur kemampuan pemerintah daerah dalam membiayai penyelenggaraan pemerintahan sendiri dengan membandingkan pendapatan asli daerah (PAD) dengan subsidi pemerintah pusat dan propinsi serta pinjaman daerah. Rasio kemandirian menggambarkan ketergantungan daerah terhadap sumber dana eksternal. Semakin tinggi rasio kemandirian mengandung arti bahwa tingkat ketergantungan daerah terhadap bantuan pihak eksternal (terutama pemerintah pusat dan provinsi) semakin rendah dan demikian pula sebaiknya.

$$
\text { Rasio Kemandirian }=\frac{\text { Pendapatan Asli Daerah }}{\text { BPP atau PP }}
$$

Ilustrasi perhitungan rasio kemandirian untuk Pemerintah Daerah Kota Batu tahun anggaran 2005 yang diambil dari APBD adalah:

Rasio Kemandirian : Pendapatan Asli Daerah

$$
\text { BPP atau PP }
$$

$$
\begin{aligned}
\text { Tahun } 2005= & \frac{8 \cdot 192 \cdot 582 \cdot 863,00}{26 \cdot 216 \cdot 735 \cdot 177,00} \\
= & 31,25 \%
\end{aligned}
$$

Berdasarkan ilustrasi di atas penulis dapat memberikan penjelasan untuk penerapan pengukuran kinerja rasio kinerja keuangan pada Pemerintah 
Daerah Kota Batu dengan menggunakan Rasio Kemandirian menunjukkan hasil perhitungan $31,25 \%$. Hal ini menunjukkan ketergantungan Pemerintah Daerah Kota Batu terhadap sumber dana eksternal (terutama pemerintah pusat dan provinsi) pada tahun 2005 semakin tinggi .

Perhitungan rasio kemandirian tahun anggaran 2006 sampai dengan tahun anggaran 2009 dapat dilihat di lampiran 10. Tabel perkembangan rasio kemandirian Pemerintah Daerah Kota Batu tahun anggaran 2005 sampai dengan tahun anggaran 2009.

Tabel 4.7

Perkembangan Rasio Kemandirian Pemerintah Daerah Kota Batu Tahun 2005-2009

\begin{tabular}{cc}
\hline Tahun & Rasio Kemandirian \\
\hline 2005 & $31,25 \%$ \\
2006 & $78,85 \%$ \\
2007 & $50,93 \%$ \\
2008 & $93,52 \%$ \\
2009 & $36,82 \%$ \\
\hline
\end{tabular}

Sumber: Bag. Keu. Pemerintah Daerah Kota Batu, 2005-2009, Diolah

Berdasarkan tabel di atas dapat disimpulkan bahwa tahun anggaran 2005 ke tahun anggaran 2006 mengalami kenaikan sebesar 47,6\% dari $31,25 \%$ menjadi 78,85\%, di tahun anggaran 2006 ke tahun anggaran 2007 mengalami penurunan sebesar $27,92 \%$ yaitu dari $78,85 \%$ menjadi $50,93 \%$, di tahun anggaran 2007 ke tahun anggaran 2008 juga mengalami kenaikan sebesar $42,59 \%$ dari $50,93 \%$ menjadi $93,52 \%$, yang terakhir tahun anggaran 2008 ke tahun 2009 mengalami penurunan sangat drastis sebesar $56,7 \%$ dari $93,52 \%$ menjadi $36,82 \%$.

\section{Rasio Aktivitas}

Rasio Aktivitas di sini di bagi menjadi 2 (dua) rasio yaitu:

\section{Rasio Belanja Aparatur terhadap Total Belanja}

Rasio ini dimaksudkan untuk mengetahui proporsi belanja aparatur daerah terhadap total belanja yang dikeluarkan pemerintah daerah.

Rasio Belanja Aparatur $=$ Belanja Aparatur Total Belanja 
llustrasi perhitungan rasio belanja aparatur daerah untuk Pemerintah Daerah Kota Batu tahun anggaran 2005 yang diambil dari APBD adalah:

$$
\begin{aligned}
& \text { Rasio Belanja Aparatur : } \frac{\text { Belanja Aparatur }}{\text { Total Belanja }} \\
& \begin{aligned}
\text { Tahun } 2005= & \frac{78.090 .187 .673,00}{171.422 .483 .146,00} \\
= & 45,55 \%
\end{aligned}
\end{aligned}
$$

Berdasarkan ilustrasi di atas penulis dapat memberikan penjelasan untuk penerapan pengukuran kinerja rasio kinerja keuangan pada Pemerintah Daerah Kota Batu dengan menggunakan rasio belanja aparatur daerah menunjukkan hasil perhitungan 45,55\%.

Perhitungan rasio belanja aparatur daerah tahun anggaran 2006 sampai dengan tahun anggaran 2009 dapat dilihat di lampiran 11. Tabel perkembangan rasio aktivitas untuk rasio belanja aparatur Pemerintah Daerah Kota Batu tahun anggaran 2005 sampai dengan tahun anggaran 2009.

Tabel 4.8

Perkembangan Rasio Belanja Aparatur Daerah Pemerintah Daerah Kota Batu Tahun 2005-2009

\begin{tabular}{cc}
\hline Tahun & $\begin{array}{c}\text { Rasio Belanja Aparatur } \\
\text { Daerah }\end{array}$ \\
\hline 2005 & $45,55 \%$ \\
2006 & $42,62 \%$ \\
2007 & $37,59 \%$ \\
2008 & $40,18 \%$ \\
2009 & $39,88 \%$ \\
\hline
\end{tabular}

Sumber: Bag. Keu. Pemerintah Daerah Kota Batu, 2005-2009, Diolah

Berdasarkan tabel di atas dapat disimpulkan bahwa tahun anggaran 2005 ke tahun anggaran 2006 mengalami penurunan sebesar 2,93\% dari 45,55\% menjadi 42,62\%, di tahun anggaran 2006 ke tahun anggaran 2007 mengalami penurunan sebesar $5,03 \%$ yaitu dari $42,62 \%$ menjadi $37,59 \%$, di tahun anggaran 2007 ke tahun anggaran 2008 juga mengalami kenaikan sebesar $2,59 \%$ dari $537,59 \%$ menjadi $40,18 \%$, yang terakhir tahun anggaran 2008 ke tahun 2009 mengalami penurunan sebesar 0,3\% dari 40,18\% menjadi $39,88 \%$. 


\section{Rasio Belanja Pelayanan Publik terhadap Total Belanja}

Rasio ini dimaksudkan untuk mengetahui proporsi belanja pelayanan publik terhadap total belanja yang dikeluarkan pemerintah daerah.

Rasio Belanja Pelayanan Publik = Belanja Pelayanan Publik Total Belanja

Ilustrasi perhitungan rasio belanja pelayanan publik untuk Pemerintah Daerah Kota Batu tahun anggaran 2005 yang diambil dari APBD adalah:

$$
\begin{aligned}
& \text { Rasio Belanja Pelayanan : Belanja Pelayanan Publik } \\
& \text { Total Belanja } \\
& \begin{aligned}
\text { Tahun } 2005= & \frac{93.332 .295 .473,00}{171.422 .483 .146,00} \\
= & 54,45 \%
\end{aligned}
\end{aligned}
$$$$
\text { Total Belanja }
$$

Berdasarkan ilustrasi di atas penulis dapat memberikan penjelasan untuk penerapan pengukuran kinerja rasio kinerja keuangan pada Pemerintah Daerah Kota Batu dengan menggunakan rasio belanja pelayanan publik menunjukkan hasil perhitungan $54,45 \%$. Hal ini menunjukkan semakin rendah persentase dana yang dialokasikan untuk belanja aparatur daerah berarti presentase belanja pelayanan publik yang digunakan untuk menyediakan sarana dan prasarana ekonomi masyarakat semakin besar.

Perhitungan rasio belanja pelayanan publik tahun anggaran 2006 sampai dengan tahun anggaran 2009 dapat dilihat di lampiran 11. Tabel perkembangan rasio aktivitas untuk rasio belanja pelayanan publik Pemerintah Daerah Kota Batu tahun anggaran 2005 sampai dengan tahun anggaran 2009.

Tabel 4.9

Perkembangan Rasio Belanja Pelayanan Publik Pemerintah Daerah Kota Batu Tahun 2005-2009 Tahun Rasio Belanja Pelayanan Publik

\begin{tabular}{l|l}
\hline 2005 & $54,45 \%$ \\
2006 & $57,38 \%$ \\
2007 & $22,19 \%$ \\
\hline
\end{tabular}




\begin{tabular}{cc}
\hline 2008 & $22,33 \%$ \\
2009 & $26,73 \%$ \\
\hline Sumber: Bag. Keu. Pemerintah Daerah Kota Batu, 2005-2009, Diolah
\end{tabular}

Berdasarkan tabel di atas dapat disimpulkan bahwa tahun anggaran 2005 ke tahun anggaran 2006 mengalami kenaikan sebesar 2,93\% dari $54,45 \%$ menjadi 57,38\%, di tahun anggaran 2006 ke tahun anggaran 2007 mengalami penurunan sebesar $35,91 \%$ yaitu dari $57,38 \%$ menjadi $22,19 \%$, di tahun anggaran 2007 ke tahun anggaran 2008 juga mengalami kenaikan sebesar $0,14 \%$ dari $22,19 \%$ menjadi $22,33 \%$, yang terakhir tahun anggaran 2008 ke tahun 2009 mengalami kenaikan sebesar 4,4\% dari 22,33\% menjadi 26,73\%, dikarenakan pada tahun 2007 sampai dengan tahun 2009 prosentase dana yang dialokasikan untuk belanja aparatur daerah tinggi maka untuk prosentase belanja pelayanan publik yang digunakan untuk menyediakan sarana dan prasarana ekonomi masyarakat rendah.

\section{DSCR}

Debt Service Coverage Ratio (DSCR) merupakan perbandingan antara jumlah pendapatan asli daerah (PAD), bagian daerah (BD) dari pajak bumi dan bangunan, bea perolehan hak atas tanah dan bangunan (BPHTB), penerimaan sumber daya alam, dan bagian daerah lainnya serta dana alokasi umum (DAU) setelah dikurangi belanja wajib (BW), dengan pemjumlahan angsuran pokok, bunga, biaya pinjaman lainnya yang jatuh tempo.

$$
\mathrm{DSCR}=\frac{(\mathrm{PAD}+\mathrm{BD}+\mathrm{DAU})-\mathrm{BW}}{(\mathrm{PA}+\mathrm{B}+\mathrm{BP})}
$$

llustrasi perhitungan debt service coverage ratio untuk Pemerintah Daerah Kota Batu tahun anggaran 2005 yang diambil dari APBD adalah:

DSCR : $(P A D+B D+D A U)-B W$

$(\mathrm{PA}+\mathrm{B}+\mathrm{BP})$

Tahun $2005=(8.192 .582 .863+137.537 .348 .923+104.489 .000 .000)-$ $\underline{171.422 .483 .146}$

15.750 .000 .000

$$
=5,00 \%
$$


Berdasarkan ilustrasi di atas penulis dapat memberikan penjelasan untuk penerapan pengukuran kinerja rasio kinerja keuangan pada Pemerintah Daerah Kota Batu dengan menggunakan debt service coverage ratio menunjukkan hasil perhitungan 5,00\%. Hal ini menunjukkan Pemerintah Daerah Kota Batu mampu membayar pokok angsuran, bunga dan biaya pinjaman lainnya yang jatuh tempo.

Perhitungan debt service coverage ratio tahun anggaran 2006 sampai dengan tahun anggaran 2009 dapat dilihat di lampiran 12. Tabel perkembangan debt service coverage ratio Pemerintah Daerah Kota Batu tahun anggaran 2005 sampai dengan tahun anggaran 2009.

Tabel 4.10

Perkembangan Debt Service Coverage Ratio Pemerintah Daerah Kota Batu Tahun 2005-2009

\begin{tabular}{cc}
\hline Tahun & $\begin{array}{c}\text { Debt Service Coverage } \\
\text { Ratio }\end{array}$ \\
\hline 2005 & $5,00 \%$ \\
2006 & $9,27 \%$ \\
2007 & $121,05 \%$ \\
2008 & $17,51 \%$ \\
2009 & $0,00 \%$ \\
\hline
\end{tabular}

Sumber: Bag. Keu. Pemerintah Daerah Kota Batu, 2005-2009, Diolah

Berdasarkan tabel di atas dapat disimpulkan bahwa tahun anggaran 2005 ke tahun anggaran 2006 mengalami kenaikan sebesar 4,27\% dari 5,00\% menjadi 9,27\%, di tahun anggaran 2006 ke tahun anggaran 2007 mengalami penurunan sebesar $(85,83) \%$ yaitu dari $9,27 \%$ menjadi $(76,56) \%$, di tahun anggaran 2007 ke tahun anggaran 2008 juga mengalami penurunan sebesar $63,76 \%$ dari $(76,56) \%$ menjadi $(12,80) \%$, yang terakhir tahun anggaran 2008 ke tahun 2009 mengalami kenaikan sebesar 12,80\% dari $(12,80) \%$ menjadi $0,00 \%$.Grafik pengukuran kinerja rasio keuangan sebagai berikut: 


\section{Grafik 4.4 \\ Perkembangan Rasio Keuangan Pemerintah Daerah Kota Batu \\ Tahun Anggaran 2005-2009}

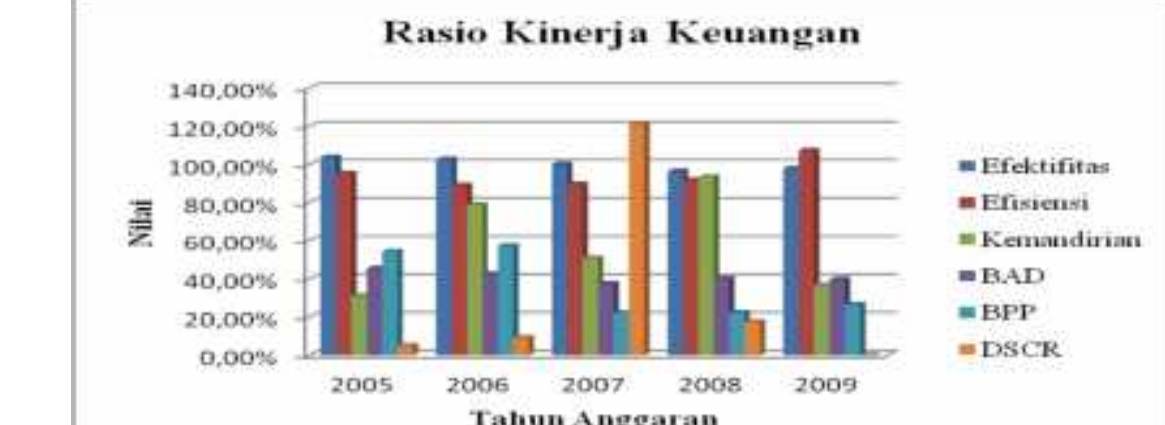

Sumber: Bag. Keu. Pemerintah Daerăh Köta Batu Tahun 2005-2009,

Diolah

\section{PENUTUP}

Hasil penelitian dari perhitungan analisis data anggaran pendapatan belanja daerah (APBD) dan realisasi anggaran pendapatan belanja daerah (RAPBD) Pemerintah Daerah Kota Batu selama tahun 2005 sampai dengan tahun 2009 dapat disimpulkan sebagai berikut: (1) Berdasarkan teknik pengukuran value for money menunjukkan: rasio ekonomi tahun 2005 sampai dengan tahun 2009 menunjukkan bahwa kinerja Pemerintah Daerah Kota Batu ekonomis dalam merealisasilan pengeluaran karena rasionya kurang dari $100 \%$. Rasio efisiensi tahun 2005 sampai dengan tahun 2009 menunjukkan bahwa kinerja Pemerintah Daerah Kota Batu secara umum cukup efisien karena realisasi biayanya lebih tinggi dibandingkan dengan realisasi pendapatannya; rasio efektifitas tahun 2005 sampai dengan 2009 menunjukkan bahwa kinerja Pemerintah Daerah Kota Batu secara umum efektif karena hasil rasio nya lebih dari $100 \%$. Hasil diatas dapat disimpulkan bahwa kinerja Pemerintah Daerah Kota Batu ditinjau dari konsep value for money sudah baik karena telah memenuhi ekonomis, efisiensi dan efektifitas.

Berdasarkan analisis rasio keuangan: Hasil rasio efektivitas Pemerintah Daerah Kota Batu dari tahun 2005 sampai 2009 dalam merealisasikan pendapatan di katagorikan kurang baik; Hasil rasio efisiensi Pemerintah Daerah Kota Batu dapat dikatakan efisien meski mengalami kenaikan, sebab rasio selama tahun 2005 sampai dengan 2008 dibawah 1 (satu) atau $100 \%$ tetapi pada tahun 2009 tidak dapat dikatakan efisien dikarenakan hasil rasio efisiensi nya diatas 1 (satu) atau 100\%; Hasil dari rasio kemandirian Pemerintah Daerah Kota Batu pada tahun 2005 sampai dengan 2009 secara umum rasio 
kemandirian telah baik dikarenakan dapat mengurangi dan mempertahankan ketergantungan terhadap pihak eksternal (terutama pemerintah pusat dan provinsi; Hasil analisis rasio aktivitas menunjukkan bahwa penggunaan dana anggaran pendapatan belanja daerah (APBD) dari tahun 2005 sampai dengan 2009 menunjukkan bahwa sebagian besar dana yang dimiliki Pemerintah Daerah Kota Batu masih diprioritaskan untuk kebutuhan belanja aparatur daerah sehingga rasio belanja pelayanan publik terhadap APBD masih relatif kecil; Hasil perhitungan debt service coverage ratio (DSCR) Pemerintah Daerah Kota Batu tahun 2005 sampai dengan 2009 di katagorikan baik karena hasilnya DSCR minimal 2,5; Hasil diatas dapat disimpulkan bahwa kinerja Pemerintah Daerah Kota Batu ditinjau dari analisis rasio keuangan harus diperbaiki lagi karena pada rasio efektifitasnya hasilnya berada dibawah $100 \%$, pada rasio aktivitasnya perlu diperbaiki lagi karena dana yang dimiliki masih diprioritaskan untuk kebutuhan belanja aparatur daerah.

\section{DAFTAR PUSTAKA}

Adibrata, Achmad Basuki. 2010. Kemungkinan Penerapan Value For Money Dan Balanced Scorecard Sebagai Alternatif Pengukuran Kinerja Dinas Pendapatan, Pengelolaan Keuangan, Dan Aset Kota Surakarta. Universitas Sebelas Maret Surakarta.

Bastian, Indra. 2001. Akuntansi Sektor Di Indonesia. BPFE, Yogyakarta.

Ella Syahputri, 2011: Peraturan Pelayanan Publik Wajib Disesuailan Dengan UU, (Online), http://seputar-indonesia.comeze.com/2011/06/ seputarindonesia-peraturan-pelayanan-publik-wajib-disesuaikan-dengan-uu/, diakses 21 Juni 2011)

Halim,Abdul. 2007. Akuntansi Sektor Publik: Akuntansi Keuangan Daerah. Salemba Empat, Jakarta.

Harian Bhirawa, 2011: Kota Batu Sambut Visit Of East Java 2011, (Online), http://www. harianbhirawa. co.id/_ekonomi/22787-kota-batu-sambut-visitof-east-java-2011, diakses 11 Januari 2011)

Kompas, 2011: Survey Integritas Sektor Pelayanan Publik: KPK Beri Rapor Merah Untuk DKI, (Online), http:// infokorupsi.com/id/ korupsi.php? $\underline{\mathrm{ac}=8848 \& \mathrm{I}=\text { survey-integritas-sektor-pelayanan-publik-kpk-beri-rapor }}$ merah-untuk-dki, diakses 9 April 2011)

Mahsun, Mohammad. 2006. Pengukuran Kinerja Sektor Publik. BPFE, Yogyakarta. 
Mardiasmo. 2000. Akuntansi Keuangan Dasar. BPFE, Yogyakarta.

Mardiasmo. 2002. Akuntansi Sektor Publik. ANDI, Yogyakarta.

Mardiasmo. 2005. Akuntansi Sektor Publik. ANDI, Yogyakarta.

Mardiasmo. 2007. Otonomi dan Manajemen Keuangan Daerah. ANDI, Yogyakarta.

Mardiasmo. 2009. Akuntansi Sektor Publik. ANDI, Yogyakarta.

Nunuk. 2008. Dinas Pendidikan Kota Yogyakarta. Yogyakarta.

Nusantara, 2011: Isu Uang Lauk Pauk Dihapus, PNS Resah, (Online), http://www.jpnn.com/index.php?mib=berita.detail\&id=103834, diakses 21 November 2011)

Sari, Ristien Armitalia. 2010. Pengukuran Kinerja Keuangan Pemerintah Daerah Kota Malang. Perguruan Tinggi ASIA Malang.

Situs Resmi Pemerintah Daerah Kota Batu, 2011: Visi dan Misi Kota Batu, (Online), http://www.batukota.go.id/pemerintah/page.visi-dan-misi-kotabatu.html, diakses 27 Oktober 2011)

Sugiyono. 2006. Statiska Untuk Penelitian, Cetakan Sembilan, CV. Alfabeta, Bandung.

Sugiyono. 2011. Metode Penelitian Kuantitatif Kualitatif Dan R\&D. Cetakan ke Tigabelas, CV. Alfabeta, Bandung.

Suyono. 2000. Pengukuran Kinerja Menggunakan Value For Money Sebelum Dan Sesudah Penerapan Otonomi Daerah Pada Pemerintahan Kota Malang. Universitas Muhammadiyah Malang.

Undang-Undang No. 32 Tahun 2004 tentang Pemerintah Daerah.

Ulum, Ihyaul MD. 2005. Akuntansi Sektor Publik. Penerbitan Universitas Muhammadiyah Malang.

Widiana, Hestina Hari.2005. Pengukuran Kinerja Organisasi Sektor Publik Dengan Menggunakan Pendekatan Balanced Scorecard. Universitas Brawijaya Malang.

Yuanda, Angel. 2007. Pengukuran Kinerja Organisasi Sektor Publik Menggunakan Pendekatan Value For Money (Studi Kasus Pada Pemerintah Kota Blitar). Universitas Muhammadiyah Malang. 